УДК 902(470.67)

\author{
РАСКОПКИ ДЕРБЕНТСКОГО ПОСЕЛЕНИЯ В 2015 Г. \\ (Работы проведены при финансовой поддержке РГНФ, \\ проект 15-01-18016е «Археологические исследования в зоне Дербента») \\ М.С. Гаджиев,
}

доктор исторических наук, профессор ДГУ, зам Председателя Дагестанского научного центра РАН, зав. Отделом археологии Института истории, археологии и этнографии Дагестанского научного центра РАН? Махачкала,

А.Л. Будайчиев,

старший лаборант-исследователь Отдела охранных раскопок Института истории, археологии и этнографии Дагестанского научного центра РАН? Махачкала,

А.М. Абдулаев,

аспирант Отдела археологии Института истории, археологии и этнографии Дагестанского научного центра РАН, Махачкала,

К.Б. Шаушев,

аспирант Отдела археологии Института истории, археологии и этнографии Дагестанского научного центра РАН, Махачкала

murgadj@rambler.ru

Аннотация: Статья посвящена результатам проведенных в сезоне 2015 года Дербентской археологической экспедицией по гранту Российского гуманитарного научного фонда раскопок Дербентского поселения, начатых в 2012 году. Поселение предшествовало возведению Дербентского оборонительного комплекса в конце 560-х гг. и было постепенно оставлено после сооружения нового города, получившего новое имя Дербент (Дарбанд). Работы производились в южном секторе раскопа XXV, где были вскрыты культурные напластования, строительные, хозяйственные остатки (стены помещений, хозяйственные ямы и др.), датируемые III-VI вв., средневековые мусульманские захоронения, впущенные в культурный слой. В результате проведенных работ получены разнообразные археологические находки. Среди разнообразных находок особый интерес представляет бронзовая поясная пряжка, найденная в хозяйственной яме № 18 , связанной со слоем 3 , и представляющая собой важный хронологический индикатор - она по аналогиям датируется последними десятилетиями IV в. - началом V в. н.э. Подобная пряжка была найдена в раскопе и в сезоне 2014 г. в хозяйственной яме № 12, также стратиграфически связанной с отложением слоя 3. Эти пряжки позволяют сузить абсолютную дату ям № 12 и № 18 до конца IV - начала V в. н.э. Вместе с другими хронологически показательными находками (в том числе образцами так называемой сасанидской керамики) они служат опорой для датировки культурных напластований раскопа и связанных с ними строительных и хозяйственных объектов. Полученные материалы (фрагменты керамической посуды, изделия из керамики, кости, бронзы, железа, камня) характеризуют культуру и быт населения Дербентского поселения, идентифицируемого с городом-крепостью Чор/Чол, известным древним армянским, грузинским, 
сирийским, ранневизантийским и арабским авторам и выступавшим важным административнополитическим и религиозным центром Восточного Кавказа.

Ключевые слова: Дербент, Чор, поселение, поздняя античность, раннее средневековье, сасанидская керамика.

\title{
EXCAVATIONS OF THE DERBENT SETTLEMENT IN 2015
}

\author{
M.S. Gadzhiev,
}

Doctor of Historical Sciences, Professor DSU, Deputy Chairman of the Dagestan Scientific Center, Russian Academy of Sciences, Head. Department of Archaeology, Institute of History, Archaeology and Ethnography of the Dagestan Scientific Center RAS. Makhachkala,

A.L. Budaychiev,

Senior laboratory researcher of the Department of protection of excavations of the Institute of History, Archaeology and Ethnography of Dagestan Scientific Center, Russian Academy of Sciences. Makhachkala,

A.M. Abdulaev,

Graduate student of the Department of Archaeology, Institute of History, Archaeology and Ethnography of the Dagestan Scientific Center, RAS, Makhachkala,

K.B. Shaushev,

Graduate student of the Department of Archaeology, Institute of History, Archaeology and Ethnography of the Dagestan Scientific Center, RAS, Makhachkala,

murgadj@rambler.ru

Abstract. The article presents the results of the excavations of the Derbent settlement conducted by the Derbent archeological expedition in 2015 within the framework of the grant of the Russian Foundation for Humanities, which started in 2012. The settlement predated the construction of the Derbent defensive complex in late 560s and it was gradually left after the construction of a new town, which was named Derbent (Darband). The excavations carried out in the southern sector of excavation site XXV revealed cultural strata, construction and household remains (walls of rooms, pits, etc.) dated back to the $3^{\text {rd }}-6^{\text {th }}$ centuries, and medieval Muslim burials in the cultural layer. As a result of the works, a variety of archaeological finds were obtained. Among the various finds, of special interest is a bronze belt clasp found in pit 18, which is associated with layer 3 and represents an important chronological indicator - according to its analogies it dates back to the last decades of the $4^{\text {th }}$ - early $5^{\text {th }}$ centuries AD. In 2014 during the excavations, a similar clasp was found in pit 12, which stratigraphically is also associated with deposits of layer 3 . These clasps allow narrowing the absolute date of pits 12 and 18 to late $4^{\text {th }}-$ early $5^{\text {th }}$ centuries AD. Alongside with other chronologically indicative finds (including samples of the so-called Sasanian ceramics), they give support to dating of the cultural strata of the excavation site and associated constructions and household objects. The obtained materials (fragments of ceramic ware, objects made of ceramics, bone, bronze, iron, stone) characterize the culture and life of the population of the Derbent settlement, identified with the walled town Chor/Chol, known to ancient Armenian, Georgian, Syrian, early Byzantine and Arab authors, and which was an important administrative, political and religious center of the East Caucasus. 
Keywords: Derbent, Chor, settlement, Late Antiquity, Early Middle Ages, Sasanian ceramics.

В сезоне 2015 г. Дербентская археологическая экспедиция ИИАЭ ДНЦ РАН продолжила раскопки в Дербенте - на территории Дербентского поселения [топографическое описание Дербентского поселения см.: 5, с. 108-109], хронологически предшествовавшего возведению Дербентского оборонительного комплекса в середине VI в. н.э. (точнее - в конце 560-х гг.). Работы производились на заложенном в 2012 г. раскопе XXV (рис. 1), расположенном в 93 м к ЮВ от угловой южной башни цитадели Нарын-кала середины VI в. (рис. 1).

В сезонах 2012-2014 гг. на раскопе XXV были выявлены культурные напластования (слои 15), датируемые в диапазоне от первых веков н.э. до VI в., связанные с ними архитектурно-бытовые остатки (стены 1-8, вымостки 1-4, каменная база колонны, опорные камни столбов, глинобитные полы, очаг, скопления керамики, хозяйственные ямы 1-15, гончарная печь), разнообразные находки (фрагменты керамической посуды, изделия из керамики, кости, бронзы, железа, камня, предметы печного припаса), а также средневековые мусульманские захоронения (погр. 1-16), впущенные в культурный слой древнего поселения [5, с. 108-129; 6, с. 144-173; 7, с. 169-187].

В сезоне 2015 года раскоп был расширен в южном направлении на 24 кв. м - новые квадраты (2х2 м) получили обозначения а-7, a-8, 6-7, б-8, в-7, в-8, затем была осуществлена прирезка (6x0,5 м) в восточном направлении к кв. в-6, в-7, в-8 с целью выявления внешнего контура стены 4. Общая площадь раскопа в 2015 г. достигла 112 кв. м (рис. 2).

Работы начались с вскрытия слоя 4 в кв. а-5 и а-6 (рис. 2). Слой 4 представляет собой серокоричневый средней плотности суглинок с включениями мелких древесных угольков, перекрытый сверху слоем 3. Из слоя происходит только 8 обломков керамической посуды, в т.ч. фрагменты отогнутого наружу венчика коричневоглиняного сосуда с серым изломом в тесте, стенки коричневоглиняного лощеного кувшина, покрытого каннелюрами, стенок красно- и коричневоглиняных столовых сосудов (2 экз.) и коричневоглиняных кухонных сосудов (4 экз.). С отметки $-2,45$ м, следовал материковый грунт, представляющий характерные каштановые почвы с известковыми фракциями.

В ходе вскрытия слоя 4 на границе в кв. а-5 и а-6 вплотную к западной стенке раскопа и рядом с исследованной в 2014 г. хозяйственной ямой 12 было выявлено темно-серое, насыщенное мелкими древесными угольками пятно хозяйственной ямы 15 (рис. 2), выделяющееся на фоне коричневого материкового грунта. Большая часть ямы уходила в западный борт раскопа, в площади раскопа оказался ее восточный сектор. Судя по выявленной части, яма имела неправильную цилиндрическую форму, диаметр ок.1,3 м; глубина - ок.0,9 м. Заполнение верхней части (ок.25 см) представляло черно-серый рыхлый грунт (супесь), насыщенный мелкими древесными угольками. Нижняя часть заполнения - светло-коричневый суглинок, в котором встречались мелкие фрагменты турлука. Из ямы происходит 11 обломков керамической посуды, в т.ч. фрагменты невыраженного венчика коричневоглиняного широкогорлого горшка с примесью песка в тесте, стенки с основаниями ленточной ручки розовоглиняного красноангобированного лощеного сосуда с примесью песка и вкраплениями шамота, стенок красноглиняных столовых (3 экз.) и коричневоглиняных кухонных сосудов (5 экз.).

Стратиграфическое положение ямы 15 связано с началом отложения перекрывающего ее слоя 4, который ранее был предварительно датирован сер./концом III- сер./концом IV в. [7, с. 176].

Как уже отмечалось, в 2015 г. раскоп был расширен в южном направлении. Здесь были вскрыты три верхних культурных слоя и впущенные в слой поселения средневековые погребения.

Слой 1 (слой пахоты), толщиной на данном участке от 30 до 40-50 см, представляет серый, средней плотности комковатый суглинок с включением небольших бутовых камней и незначительного количества древесных угольков. Из слоя происходит значительное количество обломков керамической посуды, носящей перемешанный разновременный характер и представляющей две хронологические группы. Здесь представлены 6 фрагментов глазурованной керамики домонгольского времени (рис. 4, 8-11), большое количество раннесредневековой (сасанидского времени) красно- и коричневоглиняной тарной (в т.ч. штрихованной) (рис. $3,3,15$, $28-30,4,16,18$ ) и столовой керамики, в т.ч. сасанидской (рис. $3,30,34,35,4,17,21,22$ ), красноглиняной, в т.ч. кувшины-ойнохои (рис. $4,12,5,1$ ), коричневоглиняной 
белоангобированной, розово- и бежевоглиняной красноангобированной и красноглиняной каннелюрованной (рис. $3,12,27,32,4,19$ ) столовой керамики, серо- и коричневоглиняной кухонной.

В слое 1 в кв. в-7 на отметке -1,13 м найден хорошей сохранности уникальный медный фельс (диаметр 18-19 мм) (рис. 7, 7) чекана наместника Арминийи и Азербайджана Марвана ибн Мухаммада 122 г. по хиджре / 740 г. в ал-Бабе (Дербент) (определение Г.В. Злобина).

Слой 2 представляет средней плотности суглинок светло-серого цвета, с редкими вкраплениями древесных угольков, насыщенный мелким и средним, реже крупным бутовым камнем, иногда образующим скопления и завалы, среди которых встречены и обломки зернотерок. Слой имел понижение с Ю3 на СВ соответственно рельефу местности. Толщина слоя - от 20 см до $55 \mathrm{~cm}$.

В слое найдено большое количество фрагментов керамической посуды. Она представлена обломками столовой, кухонной, тарной керамики, характерной для середины I тыс. н.э., точнее для V-VI вв. Это те же указанные выше технико-технологические группы. Показательные экземпляры представлены фрагментами:

- коричневоглиняных кувшин-ойнохой с пуговичными налепами-«глазками» по бокам слива (рис. 6, 17-19);

- горла коричневоглиняного кувшина со сливным носиком, пуговичными налепами«глазками» по бокам слива и тремя рядами круглых вдавлений палочкой с крестообразным рисунком (рис. 6, 20);

- низкой горловины тарного сосуда с насечками по верху утолщенного венчика и сплошной наружной штриховкой горла (рис. 6,27$)$;

- широко- и низкогорлого коричневоглиняного белоангобированного сасанидского сосуда (хум?) с утолщенным подквадратным в сечении венчиком с легкой обводящей канавкой по наружной стороне (рис. 6, 25);

- широкогорлого коричневоглиняного сасанидского кувшина с утолщенным подквадратным в сечении венчиком (рис. 6, 24);

- широкоустного светлокоричневоглиняного сасанидского сосуда с раздвоенным утолщенным венчиком (рис. 6, 29);

- красноангобированной столовой керамики (рис. 6,4 );

- вертикальными ручками, в том числе с поперечными или наклонными насечками, нарезками красно- и коричневоглиняных кувшинов (рис. 5, 3-11).

Из слоя 2 происходит и серия индивидуальных находок:

- каменное дисковидное пряслице, диаметром 3,5 см, толщиной 1,8-2,1 см при d отверстия = 1,1 см (рис. 7, 1);

- половинка дисковидного керамического пряслица, изготовленного из стенки сероглиняного сосуда, покрытого двусторонней штриховкой; диаметр $=4,8$ см, толщина 1,2 см (рис. 7, 2);

- бронзовое круглое в сечении колечко (серьга?) с несомкнутыми концами, диаметром 1,7 см, толщиной 0,2 см (рис. 7, 3);

- бронзовая изогнутая ленточная пластинка (спинка фибулы?) длиной 7,5 см, шириной $0,3-$ 0,6 см, толщиной 0,1 см с частично скрученным в спираль одним концом и загнутым другим концом (рис. 7, 4);

- костяная проколка длиной 9,3 см (рис. 7, 5);

- керамическое пряслице, сделанное из стенки красноглиняного сосуда, диаметром около 4 см при толщине $0,8 \mathrm{~cm}$.

Особый интерес представляет находка на границе кв. а-7 и б-7 на глубине $0,85-0,9$ м от 0 уникальной, не находящей аналогов бронзовой подвески (амулет?) (рис. 7, 6). Она имеет трехчастную композицию, в центре которой размещен куб $(1,1 \times 1,1 \mathrm{~cm})$ со срезанными углами () с отверстием в центре $(\mathrm{d}=0,5 \mathrm{~cm})$. В верхней части подвески (над кубом) размещено изображение сидящей птицы (голубя?), в нижней части (под кубом) - секировидный выступ, обращенный лезвием вниз. Общая высота подвески 3,2 см.

Кроме того, среди отмеченного скопления камней в слое найдены четыре фрагмента ладьевидных зернотерок. 
С уровня каменного завала происходят 142 фрагмента керамической посуды, представленной в целом теми же технико-технологическими группами раннесредневековой (сасанидского времени) керамики, что и из слоев 1 и 2: столовая красно- и коричневоглиняная гладкостенная керамика (рис. 4, 13); сасанидская керамика (рис. 4, 21, 22); редкая красноглиняная каннелюрованная (рис. 4, 19) и красноангобированная лощеная керамика; тарная красно- и коричневоглиняная гладкостенная и с одно- и двусторонней сплошной штриховкой тулова; серо- и коричневоглиняная кухонная и др.

В ходе расчистки слоя 2 и каменного завала были выявлены остатки стен, получивших продолжающееся цифровое обозначение 10 и 11 (рис. 2, 8a), функционировавшие до начала отложения слоя 2.

Стена 10 была выявлена еще в 2013 г. в кв. а-6, б-6, в-6 в виде плотного скопления крупного и среднего бутового камня, тянущегося по линии ЮЗ3-СВВ вдоль южного борта раскопа (рис. 2, 8а). При этом ряд крупных камней уходил в южный борт раскопа. Прослеженная протяженность стены составила 6 м, прослеженная ширина - от $0,8-1,2$ м (в западной части) до $0,3-0,5$ м (в восточной части), прослеженная толщина - до 0,5-0,55 м. Стена имела постепенное понижение в восточном направлении в соответствии с рельефом местности. Тогда мы обратили внимание на то, что в просветах между камнями фиксировался плотный светлый суглинок, напоминающий глиняный раствор. Однако остатков системной кладки не было прослежено. Вместе с тем, было обращено внимание на то, что данное скопление камней имеет ту же стратиграфическую ситуацию и направление, что и стена 3. Тогда было предположено, что это остатки стены, и было принято решение доисследовать этот участок в последующем при расширении раскопа в южную сторону, что и было осуществлено в 2015 г.

В ходе работ на границе кв. а-6, а-7...в-6, в-7 также были выявлены камни крупных и средних размеров, тянущиеся по линии Ю3З-СВВ (рис. 2). Ширина это развала стены составляет в среднем 0,8 м, прослеженная протяженность 6 м; западная оконечность стены уходит в западный борт раскопа, восточная, очевидно, заканчивается у восточного борта, где стена состыковывалась под прямым углом со стеной 4. В просветах между камнями прослежена сплошная, толщиной до 2025 см, масса плотного светло-коричневого суглинка/глинобита, представляющего, видимо, остатки раствора.

Стена 10 занимает то же стратиграфическое положение, что и параллельные ей стены 3 и 5 , соединяющиеся с общей для них стеной 4. Таким образом, эти стены образуют расположенные в ряд помещения.

Стена 11 была выявлена в кв. а-8, б-8, в-8, вдоль южного борта раскопа (рис. 2, 8а). Она следует параллельно стене 11 и имеет то же стратиграфическое положение. Она сложена из крупного и среднего бутового камня, иногда немного подтесанного, на глиняном растворе. Иногда в кладке использован и мелкий бут. Кладка сохранилась на высоту 1-3 ряда (22-42 см), ширина стены 45-55 см. Прослеженная длина ее 5,07 м; восточная оконечность стены 11 немного не доходит до восточного борта раскопа, а западный ее край упирается в стену 4 (см. ниже). Стену 11 на участке кв. а-8, 6-8 подстилал слой мелкого щебня и серого грунта толщиной 5-8 см, накрывавший нижележащий слой 3.

Рядом со стеной 11 на ее уровне вплотную к южному борту раскопа в кв. б-8 было зафиксировано скопление керамики № 1, представлявшее собой развал светлокоричневоглиняного сасанидского кувшина-ойнохои с высокой горловиной, сферическим туловом, плоским дном и вертикальной уплощенно-овального сечения массивной ручкой, крепящейся к краю горла и верхней части тулова; в месте перехода от плечиков к горловине и в верхней части тулова (уровне основания ручки) проходят два пояска из парных окаймляющих канавок (рис. 5, 2). Очевидно, отметка дна кувшина $(-1,01$ м от 0), стоявшего вертикально, фиксирует уровень древней дневной поверхности.

Рядом со стеной 11 в 0,36-0,45 м к СС3 от нее и параллельно ей расчищена небольшая однорядная оградка из средних и мелких бутовых и частично подправленных камней, некоторые из которых поставлены на ребро (рис. 2). Ширина оградки 0,12-0,27 м, длина 2,25 м.

Оградка своим западным концом упиралась в хозяйственную яму 19, большая часть которой «села» на контрольную бровку на границе кв. а-8 и б-8 (рис. 2). Яма имеет диаметр устья около 57 
см, усеченно-коническую форму, прослежена на глубину около 1 м; дно ямы в этом сезоне не было выявлено. Верхняя отметка ямы лежит на уровне основания стены 11 на этом участке. Яма впущена в нижележащий слой 3, прорезая глинобитный пол (см. ниже). В связи с тем, что яма расположилась непосредственно на контрольной бровке и в целях необходимости сохранения бровки до полной графической фиксации ее стратиграфии, было принято решение расчистку ямы оставить на следующий сезон. Видимое заполнение ямы представляет рыхлый серый грунт с большим количеством среднего и мелкого бутового камня в верхней части.

В результате снятия слоя 1 и частично слоя 2 и каменного завала были выявлены пять погребений в грунтовых ямах, впущенные в культурный слой. Захоронения получили продолжающуюся нумерацию - погребения №№ 17-21. Могильные ямы практически не прослеживались вследствие того, что погребения были впущены в существовавший культурный слой, и фиксировались они частично только на уровне выявленных скелетов. Представленные погребения взрослых людей (половозрастные данные еще не определены), как и ранее открытые погребения №№ 1-16, объединены в целом единым устойчивым погребальным обрядом, характеризующимся захоронением умерших в вытянутом положении на спине или с поворотом на правый бок, в простой удлиненной узкой грунтовой яме, ориентированной по линии на ЮЗЗ, ЮЗ, головой на Ю3З, Ю3, с обращенными на юг лицевыми костями черепа; руки согнуты в локтях или вытянуты вдоль туловища, или левая рука согнута, а правая - вытянута. Данный обряд представляет собой вариацию мусульманского погребального обряда и на этом основании представленные погребения могут быть отнесены к средневековому периоду. Более точная датировка в силу безынвентарности захоронений затруднена.

После снятия каменного завала и погребений в восточной части прирезки было расчищено крупное зольное пятно, насыщенное мелким щебнем. Оно имело подпрямоугольную форму размерами 2,95x1,72 м и было вытянуто по линии Ю33-СВВ, толщина 8-10 см. У его северного угла был отмечен сильно обожженный участок грунта округлой формы диаметром около 60 см, толщиной 1-2 см, вероятно, фиксирующий очажное пятно. Здесь зафиксировано скопление № 2 обломков керамической посуды. Это фрагменты чуть утолщенного венчика сероглиняного сосуда, венчика с отходящей от внешнего края массивной овальной в сечении ручкой коричневоглиняного кувшина, стенок красно- и коричневоглиняных столовых сосудов (63 экз.), в т.ч. с врезной линейно-волнистой орнаментацией (11 экз.), коричневоглиняных кухонных горшков (20 экз.), красно- и бежевоглиняных тарных сосудов (22 экз.), красноглиняного каннелюрованного (1 экз.), красно- и коричневоглиняных белоангобированных сосудов (4 экз.), красноглиняных плоских донцев (4 экз.).

Из данного крупного зольного пятна (кв. б-7, б-8, в-7, в-8) происходят 216 обломков керамической посуды, в т.ч. фрагменты:

- круглой в сечении с косыми насечками ручки красноглиняного кувшина с серым изломом (рис. 5, 12);

- венчика и плечика красноглиняного красноангобированного кувшина с основанием ручки и с примесью песка в тесте (рис. 5, 13);

- раструбовидной горловины с утолщенным венчиком красноглиняного сосуда с серым изломом (рис. 5,14$)$;

- венчика и стенки тулова сероглиняного сосуда с чернолощеной поверхностью и с двумя окаймляющими валиками (рис. 5, 15);

- венчика красноглиняного сосуда (рис. 5,16 );

- раздвоенного венчика сасанидского охристоглиняного крупного сосуда с примесью песка в тесте (рис. 5, 17);

- венчика красноглиняного кувшина с крупной ленточной ручкой и с примесью песка в тесте (рис. 5, 18);

- а также фрагменты стенок столовых гладкостенных красно- и розовоглиняных сосудов (28 экз.), в т.ч. с врезным линейно-волнистым орнаментом (5 экз.), красно- и коричневоглиняных лощеных сосудов, покрытых каннелюрами (13 экз.), розовоглиняных красноангобированных кувшинов (4 экз.), сероглиняного лощеного сосуда (1 экз.), тарных гладкостенных красно- и 
коричневоглиняных сосудов (18 экз.) и с одно- и двусторонней сплошной штриховкой тулова (26 экз.), кухонных серо- и коричневоглиняных сосудов (41 экз.) и др.

С южной стороны описанное зольное пятно, вероятно, представляющее сгоревшую деревянную конструкцию (перекрытие/навес? настил?), было ограждено описанной выше оградкой рядом со стеной 11 , а с восточной стороны примыкало к обнажившейся, лежавшей плашмя крупной плите на границе кв. в-7 и в-8 и стене 4 (рис. 2).

Каменная плита лежала в направлении ССЗ-ЮЮВ на границе кв. в-7 и в-8 (рис. 8б). Ее восточный край уходил в восточный борт раскопа. Впоследствии для выявления полностью этой плиты было принято решение расширить раскоп на данном участке путем прирезки шириной 0,5 м к кв. в-6...в-8 (рис. 2). Прирезка ставила также целью возможное выявление продолжения стены 4, пересекающей весь раскоп с ССЗ на ЮЮВ и исследованной в 2012-2014 гг. на различных участках.

Плита имеет удлиненную трапециевидную форму, ее длина 187 см, ширина в северной (узкой) части 50 см, в южной (широкой) - 80 см, толщина 18-22 см; имеет следы обработки и потертости. На верхней (лицевой) поверхности плиты расположены четыре округлой формы выемки: две из них - у северного края плиты, две - у южного края (рис. 2, 8а, 8б). Выемки у северного края имеют диаметры 9 см при глубине 4,5 см и располагались на расстоянии 12 см друг от друга параллельно северному краю плиты. Выемки у южного края имели, соответственно, диаметры 12 см и 6 см и глубины 6 см и 3,5 см и располагались на расстоянии 6 см друг от друга под углом к скошенному краю плиты.

В ходе зачистки вплотную к южному краю плиты на границе кв. в-8, г-8 была выявлена кладка из крупных, средних и мелких бутовых и немного обработанных камней, являющаяся вместе с описанной плитой продолжением стены 4 (рис. 2, 8а, 8б). Кладка двух-, трехрядная по ширине, на глиняном растворе, с аккуратной укладкой камней у внешних фасов и с забутовкой мелким бутом. Кладка продолжается и под описанной крупной плитой, которая специально была положена на данную кладку. Кладка имеет от 2 до 5 рядов камней по высоте (с учетом плиты); ряды кладки перебиваются; ширина стены $0,78-0,8$ м. Стена 4 в кв. в-8 в месте стыка со стеной 11 имеет с ней конструктивную перевязку (рис. 2, 8a), указывающую на их единовременное строительство. При этом подошва стены 4 значительно ниже подошвы стены 11. Заметим, что стыкующиеся со стеной 4 стены 3, 6, 10 также имеют более высокие отметки подошвы, нежели стена 4. Тем самым было установлено, что стена 11 возводилась при помощи эскарпа склона на данном участке. Это обычный строительный прием, используемый в горском домостроительстве.

Стена 4 на данном участке прослежена в длину на 3,35 м. У стыка со стеной 11 она упирается в южный борт раскопа. Таким образом, общая протяженность стены 4, исследованной на разных участках в 2012-2015 гг., составляет свыше 18 м. При этом она имеет продолжение в северном и южном направлении, выходя за пределы раскопа. Такая необычная протяженность стены, ее более капитальный характер (толщина стены составляет 0,65-0,8 м) по сравнению с другими стенами, ее местоположение у начала восточного склона отрога, сооружение на эскарпе склона с опорой на грань среза, примыкание к ней стен помещений с западной стороны (рис. 2) дают основание считать, что эта стена, обращенная своим наружным (восточным) фасом в сторону Прикаспийской равнины, выполняла роль наружной (внешней) фасадной стены домостроений Дербентского поселения, выполняя, тем самым, и оборонительную функцию. Такой принцип архитектурнопространственного оформления поселения характерен для традиционной горской архитектуры Дагестана, когда наружные фасадные стены домостроений, расположенных по периметру поселения, выделяются своей протяженностью и толщиной и несут и оборонительную нагрузку. Такой принцип, в частности, наблюдался и на городище Урцеки.

Касаясь назначения крупной плиты, положенной на кладку стены 4, принимая во внимание ее стратиграфическое положение, соответствующее уровню древней дневной поверхности (с западной стороны к ней примыкало описанное крупное зольное пятно), можно полагать, что она являлась порогом существовавшего здесь широкого (возможно, двустворчатого) прохода. Вероятно, выявленные у южного и северного края плиты парные углубления являются лунками для крепления стоек дверного косяка. 
На уровне $-1,15$ м от 0 , соответствующем древней дневной поверхности, зафиксированной зольным пятном, в кв. а-7 рядом с западным бортом раскопа была выявлена хозяйственной ямы 16 (рис. 2). Она имела цилиндрическую форму, размеры овального в плане устья 1,05×1,22 м, дно ровное, круглой формы диаметром 1,2 м; глубина ямы 1,55 м. Стенки ямы ровные, но вследствие того, что яма была впущена в культурный слой, они не всегда фиксировались четко. Яма прорезала нижележащие слои 3 и 4 и была впущена в материковый грунт. Верхняя часть заполнения ямы на толщину около 50 см представляла собой серый рыхлый золистый грунт, ниже - коричневый, средней плотности суглинок с включениями древесных угольков. В придонной

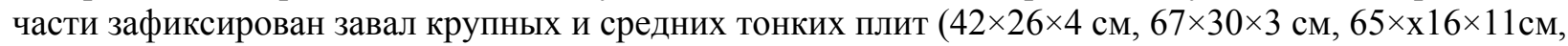
$38 \times 30 \times 9$ см, $34 \times 26 \times 9$ см). В этом завале обнаружен и обломок каменной зернотерки.

Из заполнения ямы происходит 283 фрагмента керамической посуды (в основном стенки), в т.ч. из верхней части заполнения - 120 фрагментов, из средней - 129, из нижней - 34 обломка.

Среди керамики верхней части имеются формообразующие фрагменты: утонченного венчика красноглиняного кувшина (ойнохоя?) (рис. 5, 19); отогнутого венчика сероглиняного горшка с примесью песка и толченой ракушки в тесте (рис. 5, 20); венчика розовоглиняного красноангобированного кувшина (рис. 5, 21); резко отогнутого, утолщенного венчика с вдавлениями по наружному краю красноглиняного тарного сосуда (рис. 5, 22). Здесь также представлены стенки столовых красно-, коричнево- и розовоглиняных гладкостенных сосудов (39 экз.), красно- и коричневоглиняных каннелюрованных сосудов (5 экз.), красно- и розовоглиняных кувшинов, покрытых красным и бордовым ангобом (4 экз.), сероглиняных сосудов с серой и черной лощеной поверхностью (8 экз.), кухонных серо- и коричневоглиняных сосудов (43 экз.), тарных красно- и коричневоглиняных сосудов (15 экз.), в т.ч. со сплошной одно- и двусторонней штриховкой тулова (4 экз.) и др.

Среди керамики средней части выделим фрагменты венчика красноглиняного кувшинаойнохои (рис. 5, 23), отогнутого венчика с вдавлениями по наружному краю и плечика красноглиняного тарного сосуда с двусторонней сплошной штриховкой тулова (рис. 5, 24), утонченного и слегка отогнутого венчика коричневоглиняного сосуда с примесью песка в тесте (рис. 5, 25), плечика розовоглиняного красноангобированного кувшина, раструбовидной горловины и плечика сероглиняного чернолощеного кувшина с овальной в сечении вертикальной ручкой (рис. 5, 26). Здесь также представлены стенки вышеперечисленных технологических групп керамики.

Из нижней части ямы происходят только стенки керамических сосудов, названных выше групп керамики.

Ниже слоя 2 следовал слой 3, представляющий собой светло-серый рыхлый суглинок с включениями древесных угольков. Мощность слоя колеблется от 68-70 см до 120-124 см. Отметим, что слой разделен на две примерно равные по мощности половины (слои 3а и 3б) глинобитным полом, зафиксированным частично в кв. 6-8, в-8, 6-7, в-7, частично а-8. Пол представляет слой чистого плотного коричневого суглинка толщиной 4-5 см без каких-либо фракций. Он имеет понижение с Ю3 на СВ и с ЮВ на С3. В кв. в-8 зафиксировано его примыкание к нижнему, выступающему ряду стены 4, возможно, документирующее их относительно одновременное сооружение.

На профиле южной стенки раскопа в кв. а-8 был зафиксирован срез хозяйственной ямы 20 , перекрытой сверху стеной 11 и подстилающим ее слоем щебня. Заполнение ямы (серый рыхлый грунт с древесными угольками) почти не отличается от окружающего ее слоя 3 , из-за чего она не была зафиксирована при вскрытии слоя. Яма, очевидно, имела цилиндрическую форму; прослеживаемая в профиле ширина 94-96 см, глубина ок.1,0-1,04 м. Ее стратиграфическое положение, идентичное стратиграфическому положению ямы 19, указывает, что она была сооружена на заключительном этапе отложения слоя 3 и до строительства стены 11, которая перекрывает ее.

В кв. а-8 на отметке $-2,1$ м от 0 , до которой был доведен в данном квадрате раскоп и близкой к границе слоя 3 и нижележащего слоя 4, было выявлено зольное (очажное) пятно круглой формы, диаметром около 45 см, толщиной 1-1,5 см (рис. 2), фиксирующее древний дневной уровень. 
В слое 3 найдено значительное количество фрагментов керамической посуды. Керамический комплекс слоя представлен в целом теми же технико-технологическими группами (столовая красно- и коричневоглиняная гладкостенная, заглаженная, каннелюрованная, красноангобированная, тарная штрихованная, кухонная сероглиняная и др.), что и вышележащие слои 1 и 2, что позволяет его датировать в близком хронологическом, но предваряющем диапазоне по отношению к датировке слоя 2 , изученной в 2012 г. гончарной печи $[5$, с. $114-116$, рис. 7,8$]$ и с учетом датировки слоя 3 на основании найденной в 2013 г. пряжки в яме 12, связанной с этим слоем [7, с. 172, рис. 6, 16], т.е. серединой/концом IV-V в. Отметим, что здесь встречаются и обломки серо- и коричневоглиняной с лощеной серой или черной наружной поверхностью керамики, характерной для албано-сарматского времени: это, в частности, невыделенные слабо отогнутые венчики кувшинов (рис. 9, 40, 45), гофрированные вертикальные ручки кувшинов (рис. $10,3,4)$, вертикальная ручка с пуговичными налепами в месте крепления к венчику (рис. 10, 8), часть венчика и горла кувшина-ойнохои (рис. 9, 48). Среди показательных обломков выделим фрагменты:

- венчика с утонченным краем красноглиняного кувшина, покрытого каннелюрами (рис.9,4);

- круглой в сечении ручки красноглиняного кувшина; поверхность ручки покрыта беспорядочными канавками (рис. 10, 5);

- утолщенного невыделенного венчика крупного бочковидного тарного сосуда (рис. 9, 14);

- горловины коричневоглиняного кувшина-ойнохои (рис. 9, 13);

- невыраженных венчиков красноглиняных сосудов с лощеной красноангобированной поверхностью (рис. 9, 19);

- невыделенного венчика с отходящей от внешнего края овальной в сечении ручкой коричневоглиняного кувшина с примесью толченой ракушки в тесте (рис. 10, 1 );

- коричневоглиняных кувшинов, покрытых снаружи белесым ангобом (рис. 9, 36);

- горловины с чуть утолщенным венчиком бежевоглиняного кувшина-ойнохои (рис. 9, 3);

- отогнутого невыраженного венчика с поперечными насечками по краю сероглиняного заглаженного сосуда (рис. 9, 42);

- стенки красноглиняного тарного сосуда с двусторонней штриховкой тулова и валиком с вертикальными насечками (рис. 9, 49);

- отогнутого закругленного венчика бежевоглиняного тарного сосуда с раструбовидным горлом, с серым тестом в изломе с обильной примесью шамота (рис. 9, 46);

- коричневоглиняной с обильной примесью шамота плиты-жаровни диаметром 18-20 см с пальцевым вдавлением у края.

Кроме фрагментов керамической посуды из слоя происходит серия индивидуальных находок:

- заготовка керамического пряслица (рис. 10,9) из стенки красноглиняного сосуда;

- керамическое пряслице усеченно-конической формы с чуть округлыми боками (рис. 10, 12), которые оформлены двумя рядами из штампованных кружочков-пунсонов;

- обломок каменного пряслица (рис. 10, 10);

- фрагмент керамического пряслица уплощенно-биконической формы (рис. 10, 11);

- обломок керамического штыря (рис. 10, 13);

- обломок плоской красноглиняной черепицы с бортиком;

- фрагмент железного изделия (черенок ножа?) с заклепкой;

- кусочек железного шлака;

- скопление кусочков (7 шт.) железного шлака;

- кусочек керамического шлака.

Обнаруженные в слое 3 индивидуальные находки не противоречат предложенной датировке слоя. Несколько необычным выглядит находка в слое кровельной керамиды, которые появляются в Дербенте в позднесасанидский период и распространяются в последующее время. Но исключать находки черепицы в слое IV-V вв. нельзя.

С отложением слоя 3 связаны хозяйственные ямы 17 и 18.

Хозяйственная яма 17 выявлена на границе кв. в-7, в-8 рядом со стеной 4 (рис. 2). Слабо выделяющееся более серым цветом на фоне культурного слоя пятно устья ямы было выявлено на отметке $-1,48-1,49$ м от 0 , что соответствовало примерно уровню зафиксированного в этой части 
раскопа глинобитного пола, разделявшего слой 3 на две части (см. выше). Таким образом, яма была впущена в нижнюю половину слоя 3. При этом собственно пол и пятно ямы вплотную не были зафиксированы. Устье ямы имело овальную форму размерами около 1,1×0,78 м. Заполнение ямы представляло серый, серо-коричневый рыхлый грунт с вкраплениями мелких древесных угольков, мелкого бута, с редкими зольными прослойками. Стенки ямы, вследствие того, что яма была впущена в культурный слой, а консистенция, цвет, плотность слоя и заполнения ямы были весьма близки, прослеживались плохо, особенно в ее южной и юго-восточной частях. Это обусловило решение постепенно вскрывать площадь ямы и прилегающей части слоя в южной части в надежде выявить более четкий контур ямы на более низкой глубине. С отметки $-2,2$ м и до глубины $-2,66$ м от 0 в пространстве ямы наблюдалось скопление плоских удлиненных плит и бутовых камней $(76 \times 36 \times 6$ см, $63 \times 23 \times 13 \mathrm{~cm}, 70 \times 24 \times 6 \mathrm{~cm}, 56 \times 22,5 \times 6,5 \mathrm{~cm}, 292 \times 2 \times 5 \mathrm{~cm})$, лежавших в основном наклонно по направлению ЮВ-СЗ. Очевидно, что эти камни лежали на перекрытии ямы и рухнули в нее единовременно. На глубине $-2,7$ м вскрытие ямы было остановлено и будет продолжено в следующем сезоне. Яма своей нижней расширяющейся частью заходит под стену 4 , которая накрывает восточный сектор ямы. Стратиграфическое положение ямы показывает, что она хронологически связана с завершением отложения нижней части слоя 3 и началом отложения верхней части слоя 3 , но до сооружения стены 4.

Из заполнения ямы происходит 120 фрагментов керамической посуды, представленных, главным образом обломками стенок сосудов. Среди них - те же, отмеченные выше технологические группы керамики, характерные для слоя 3: столовая красно- и коричневоглиняная гладкостенная, красноангобированная, каннелюрованная, тарная штрихованная, кухонная сероглиняная и др. Выделим показательные фрагменты:

- отогнутого венчика красноглиняного лощеного сосуда (рис. 10, 14);

- отогнутого венчика сероглиняного горшка с примесью шамота в тесте (рис. 10, 15);

- венчика сероглиняного горшка с примесью песка в тесте (рис. 10, 16);

- фрагменты невыраженных закругленных венчиков сероглиняных сосудов (рис. $10,17,18$ );

- резко отогнутого, утолщенного закругленного венчика и плечика серо-коричневого крупного горшка с примесью толченой ракушки и песка в тесте (рис. 10, 22);

- отогнутого венчика с отходящей овальной в сечении ручкой красноглиняного белоангобированного кувшина с вкраплениями толченой ракушки в тесте (рис. 10, 23);

- ленточной ручки с уступом розовоглиняного кувшина с остатками бордового ангоба на внешней поверхности и с примесью песка в тесте (рис. 10, 24);

- ленточной ручки сероглиняного сосуда с примесью песка и мелкотолченой ракушки в тесте;

- стенки розовоглиняного белоангобированного сосуда;

- стенок красноглиняных каннелюрованных лощеных кувшинов.

В заполнении ямы найдено шесть индивидуальных находок:

- фрагмент невыраженного венчика каменной чаши (рис. 10, 25);

- обломок костяной проколки (рис. 10, 26);

- стеклянная топориковидная подвеска (рис. 10, 27);

- кусок гагата со сквозным отверстием;

- обломок каменной зернотёрки;

- фрагмент (утонченный кончик) красноглиняного керамического штыря диаметром 2 см.

Среди этой категории находок хронологически показательной является фрагмент каменной чаши. Такие чаши являются характерной находкой в памятниках Дагестана III-V вв. и происходят, в частности, из раскопок Дербента, городищ Урцеки, Охли, Таргу, Вихлинского, Паласасыртского поселений, Цыйшинского, Гапшиминского могильников (сводку см.: 4, с. 168, рис. 80, 9-14). Эти чаши тщательно изготовлены из мелкозернистого песчаника и отличаются строгой симметричностью, правильными, законченными формами, гладкой поверхностью.

Хозяйственная яма 18 выявлена в кв. в-7 у стыка стен 4 и 10 (рис. 2). Круглое, диаметром 48$50 \mathrm{~cm}$, устье ямы зафиксировано на отметке $-1,75$ м. Яма имела цилиндрическую форму, ровные стенки и дно. Глубина ямы всего 38-39 см. Заполнение ее представляло серый рыхлый грунт с включением мелких древесных угольков. Из ямы происходит только 10 обломков керамической посуды, в том числе фрагменты венчика коричневоглиняного горшка с обильной примесью песка 
в тесте (рис. 10, 28), невыраженного венчика красноглиняного сосуда (рис. 10, 29), стенок коричневоглиняного кувшина, покрытого каннелюрами, красноглиняного красноангобированного кувшина, красноглиняных столовых сосудов (2 экз.), сероглиняных лощеных сосудов (4 экз.).

Особую важность имеет находка в верхней части заполнения ямы бронзовой поясной пряжки (рис. 10,30), выступающей хронологическим индикатором. Пряжка была обнаружена насаженной на скол на лопатке мелкого рогатого скота, лежавшей вертикально у западного края ямы. Пряжка овальнорамчатая, рамка слегка утолщена в передней части и немного утончена и выпрямлена в задней части, Г-образный язычок охватывает рамку на всю высоту, заходя за середину ее сечения и примыкая к ней. По форме рамки и язычка, она датируется последними десятилетиями IV в. началом V в. н.э. [8, с. 139, рис. 1, 6]. Она близка характерным для указанного времени пряжкам типа П11 по В.Ю. Малашеву [10, с. 196], которые выступают, в частности, хроноиндикатором финала черняховской культуры с датировкой последними десятилетия IV - началом V в. н.э. [1, c. $51 ; 2,268 ; 3$, с. 22,24 , рис. $12,19-22,13,2,14,6]$

Подобная пряжка была найдена в раскопе и в сезоне 2014 г. в хозяйственной яме 12, также стратиграфически связанной с отложением слоя 3 [7, с. 172, рис. 6, 16]. Эти пряжки позволяют сузить абсолютную дату ям 12 и 18 до конца IV - начала V в. и служат опорой для датировки культурных напластований раскопа и связанных с ними строительных и хозяйственных объектов.

На большей вскрывавшейся в сезоне 2015 г. части раскопа он был доведен до отметки $-2,1$ м от 0. На двух небольших участках в кв. а-7 (в месте расположения ямы 16) и в кв. в-8 и частично на прилегающих участках кв. б-8 и в-7 (в месте расположения ямы 17 и у стыка стен 4 и 11) раскоп был доведен соответственно до отметок $-2,6$ м и $-2,7$ м от 0 с целью выявления нижележащих культурных напластований.

На участке в кв. а-5...а-7 был выявлен культурный слой 4, представляющий плотный коричневый суглинок. Толщина его на исследованном участке составляет до $50 \mathrm{~cm}$, постепенно уменьшаясь в восточную сторону. Из слоя происходит незначительное количество фрагментов керамической посуды - столовой, кухонной, тарной. Показательные экземпляры представлены фрагментами:

- цилиндрической горловины с чуть отогнутым венчиком красноглиняного кувшина(рис. 9, 47);

- прямого венчика красноглиняного сосуда (рис. 9, 44);

- отогнутого венчика сероглиняного лощеного сосуда (рис. 9, 43);

- стенки с овальной в сечении ручкой сероглиняного лощеного кувшина (рис. 10, 7);

- стенок сероглиняных серо- и чернолощёных сосудов (7 экз.);

- невыраженными венчиками сероглиняных сосудов с примесью шамота в тесте (рис. 9, 50, $53,54)$;

- округлобокой сероглиняной лощеной мисочки с невысоким вертикальным бортиком с внешним ребром (рис. 9, 51);

- венчика сероглиняного сосуда-ойнохои (рис. 9, 52)

- ленточной ручки сероглиняного кувшина с коричневой заглаженной поверхностью, с обильной примесью шамота в тесте; по внешней поверхности ручки проходят два продольных желобка (рис. 9, 55);

- подпрямоугольной в сечении ручки красноглиняного белоангобированного кувшина (рис. 9,56);

- круглой в сечении руки красноглиняного сосуда (рис. 9, 57);

- красно- и коричневоглиняных столовых сосудов (12 экз.);

- коричнево- и сероглиняных кухонных сосудов (28 экз.);

- красно- и коричневоглиняных сосудов, покрытых каннелюрами (3 экз.) (рис. 9, 58);

- красноглиняного красноангобированного сосуда (1 экз.);

- тарной штрихованной керамики (3 экз.).

На отметке $-2,55$ м в кв. а-7 был обнаружен также кусочек железного шлака.

Как видно, состав керамики слоя 4 данной части раскопа близок по своим техникотехнологическим группам таковому слоя 3. В нем не представлена так называемая сасанидская керамика. Стратиграфическое положение слоя 4, предложенная датировка слоя 3 (середина/конец IV-V в.) и характер керамического комплекса слоя 4, представляющего сочетание керамики албано-сарматского времени (серолощеные сосуды) и начала раннего средневековья 
(красноангобированные, красноглиняные сосуды, штрихованная тарная керамика), отсутствие фрагментов сасанидской керамики, позволяют предварительно датировать слой 4 в рамках III середины IV в.

Ниже слоя 4 на данном участке с отметки $-2,55-2,6$ м от 0 следовал материковый грунт, представляющий характерные каштановые почвы.

В кв. в-8 и частично на прилегающих участках кв. б-8 и в-7 вокруг ямы 17 на общей площади около 1 кв. м, как отмечалось выше, раскоп был доведен до отметки $-2,7$ м. На этом участке из слоя 4 происходит 107 фрагментов керамической посуды, из них 1 венчик с фрагментом овальной в сечении вертикальной ручки сероглиняного лощеного кувшина-ойнохои, стенки красноглиняного сосуда с врезной волнистой окаймляющей линией, 2 обломка ручек коричневоглиняных заглаженных сосудов, 2 фрагмента плоских донцев красно- и коричневоглиняного сосудов, остальные - стенки различных сосудов. Последние представляют те же группы керамики, что и из слоя 4 в кв. а-7, характеризующие сочетание керамики албаносарматского времени (сероглиняная с черной и серой лощеной поверхностью - 14 экз.) и начала раннего средневековья (красноангобированная - 1 экз., каннелюрованная - 3 экз., штрихованная тарная керамика - 3 экз., красно-, коричневоглиняные сосуды).

На этом в сезоне 2015 г. на данном южном участке (кв. а-7, а-8, б-7, б-8, в-7, в-8) раскопа работы были завершены. В следующем сезоне планируется доведение раскопа на этом участке до материка на всей площади и расширение его в южном направлении. Полученные материалы предоставили новые данные для изучения стратиграфии и хронологии Дербентского поселения, изучения жизни и быта обитателей поселения.

\section{ЛИТЕРАТУРА}

1. Гавритухин И.О. Хронологические индикаторы финала черняховской культуры. I. Толстостенные кубки со шлифованной и пластической орнаментацией: конические и с выделенной ножкой (Eggers 236-238, 195; Straume IV-XI) // Сто лет черняховской культуры. Киев: Ин-т археологии НАН Украины, 1999. С. 48-86.

2. Гавритухин И.О. Финал традиций культур римского времени в Восточном Прикарпатье // Die spätromische Keiserzeit und die frühe Völkerwanderungszeit in Mittei- und Osteuropa. Kongreß Lódz. 9.-11. November 1996. Maczynska M., Grabarczyk, T. W. [Hrsg.]. Łódź : Wydaw. Uniw., 2000. S. 261-320.

3. Гавритухин И.О. Глава 1. Днепровское лесостепное левобережье. 1.2. Финал черняховской культуры // Раннеславянский мир. Вып. 9. Восточная Европа в середине I тысячелетия н.э. Отв. ред. И.О. Гавритухин, А.М. Обломский. М.: ИА РАН, 2007. С. 9-24.

4. Гаджиев М.С. Древний город Дагестана: Опыт историко-топографического и социальноэкономического анализа. М.: Восточная литература, 2002. $-320 \mathrm{c.}$

5. Гаджсиев М.С., Будайчиев А.Л. Раскопки Дербентского поселения в 2012 г. // Вестник Института истории, археологии и этнографии. № 4. 2013. С. 108-129.

6. Гаджиев М.С., Будайчиев А.Л., Абдулаев А.М. Раскопки Дербентского поселения в 2013 г. // Вестник Института истории, археологии и этнографии. № 1. 2016. С. 144-173.

7. Гаджиев М.С., Будайчиев А.Л., Абдулаев А.М., Шаушев К.Б. Раскопки Дербентского поселения в 2014 г. // Вестник Института истории, археологии и этнографии. № 3. 2016. С. 168187.

8. Кривошеев М.В., Малашев В.Ю. Хроноиндикаторы середины III - IV вв. н.э. из степных памятников Волго-Донского региона // Античная цивилизация и варварский мир ПонтоКаспийского региона: материалы Всероссийской научной конференции с международным участием, посвященной 70-летнему юбилею Б.А.Раева (Кагальник, 20-21 октября 2016 г.). Отв.ред. С.И. Лукьяшко. Ростов н/Д: Изд-во ЮНЦ РАН, 2016. С. 138-147.

9. Кудрявиев А.А. Отчет о работе Дербентской археологической экспедиции в 1987 г. // Архив ИИАЭ ДНЦ РАН. Ф. 3. ОП. 3. Д. 670.

10. Малашев В.Ю. Периодизация ременных гарнитур позднесарматского времени // Сарматы и их соседи на Дону. Ростов-на-Дону: Терра, 2000. С. 194-232. 


\section{REFERENCES}

1. Gavrituhin I.O. Hronologicheskie indikatory finala chernjahovskoj kul'tury. I. Tolstostennye kubki so shlifovannoj i plasticheskoj ornamentaciej: konicheskie i s vydelennoj nozhkoj (Eggers 236-238, 195; Straume IV-XI) // Sto let chernjahovskoj kul'tury. Kiev: Institut arheologii NAN Ukrainy, 1999. S. 48-86.

2. Gavrituhin I.O. Final tradicij kul'tur rimskogo vremeni v Vostochnom Prikarpat'e // Die spätromische Keiserzeit und die frühe Völkerwanderungszeit in Mittei- und Osteuropa. Kongreß Lódz. 9.11. November 1996. Maczynska M., Grabarczyk, T.W. [Hrsg.]. Łódź : Wydaw. Uniw., 2000. S. 261-320.

3. Gavrituhin I.O. Glava 1. Dneprovskoe lesostepnoe levoberezh'e. 1.2. Final chernjahovskoj kul'tury // Ranneslavjanskij mir. Vyp. 9. Vostochnaja Evropa v seredine I tysjacheletija n.je. Otv. red. I.O. Gavrituhin, A.M. Oblomskij. M.: IA RAN, 2007. S. 9-24.

4. Gadzhiev M.S. Drevnij gorod Dagestana: Opyt istoriko-topograficheskogo i social'nojekonomicheskogo analiza. M.: Vostochnaja literatura, 2002. - $320 \mathrm{~s}$.

5. Gadzhiev M.S., Budajchiev A.L. Raskopki Derbentskogo poselenija v 2012 g. // Vestnik Instituta istorii, arheologii i jetnografii. № 4. 2013. S. 108-129.

6. Gadzhiev M.S., Budajchiev A.L., Abdulaev A.M. Raskopki Derbentskogo poselenija v 2013 g. // Vestnik Instituta istorii, arheologii i jetnografii. № 1. 2016. S. 144-173.

7. Gadzhiev M.S., Budajchiev A.L., Abdulaev A.M., Shaushev K.B. Raskopki Derbentskogo poselenija v 2014 g. // Vestnik Instituta istorii, arheologii i jetnografii. № 3. 2016. S. 168-187.

8. Krivosheev M.V., Malashev V.Ju. 2016. Hronoindikatory serediny III - IV vv. n.je. iz stepnyh pamjatnikov Volgo-Donskogo regiona // Antichnaja civilizacija i varvarskij mir Ponto-Kaspijskogo regiona: materialy Vserossijskoj nauchnoj konferencii s mezhdunarodnym uchastiem, posvjashhennoj 70letnemu jubileju B.A.Raeva (Kagal'nik, 20-21 oktjabrja 2016 g.). Otv.red. S.I. Luk'jashko. Rostov na Donu: Izd-vo JuNC RAN, 2016. S. 138-147.

9. Kudrjavcev A.A. Otchet o rabote Derbentskoj arheologicheskoj jekspedicii v 1987 g. // Arhiv IIAJe DNC RAN. F. 3. Op. 3. D. 670.

10. Malashev V.Ju. Periodizacija remennyh garnitur pozdnesarmatskogo vremeni // Sarmaty i ih sosedi na Donu. Rostov-na-Donu: Terra, 2000. S. 194-232. 


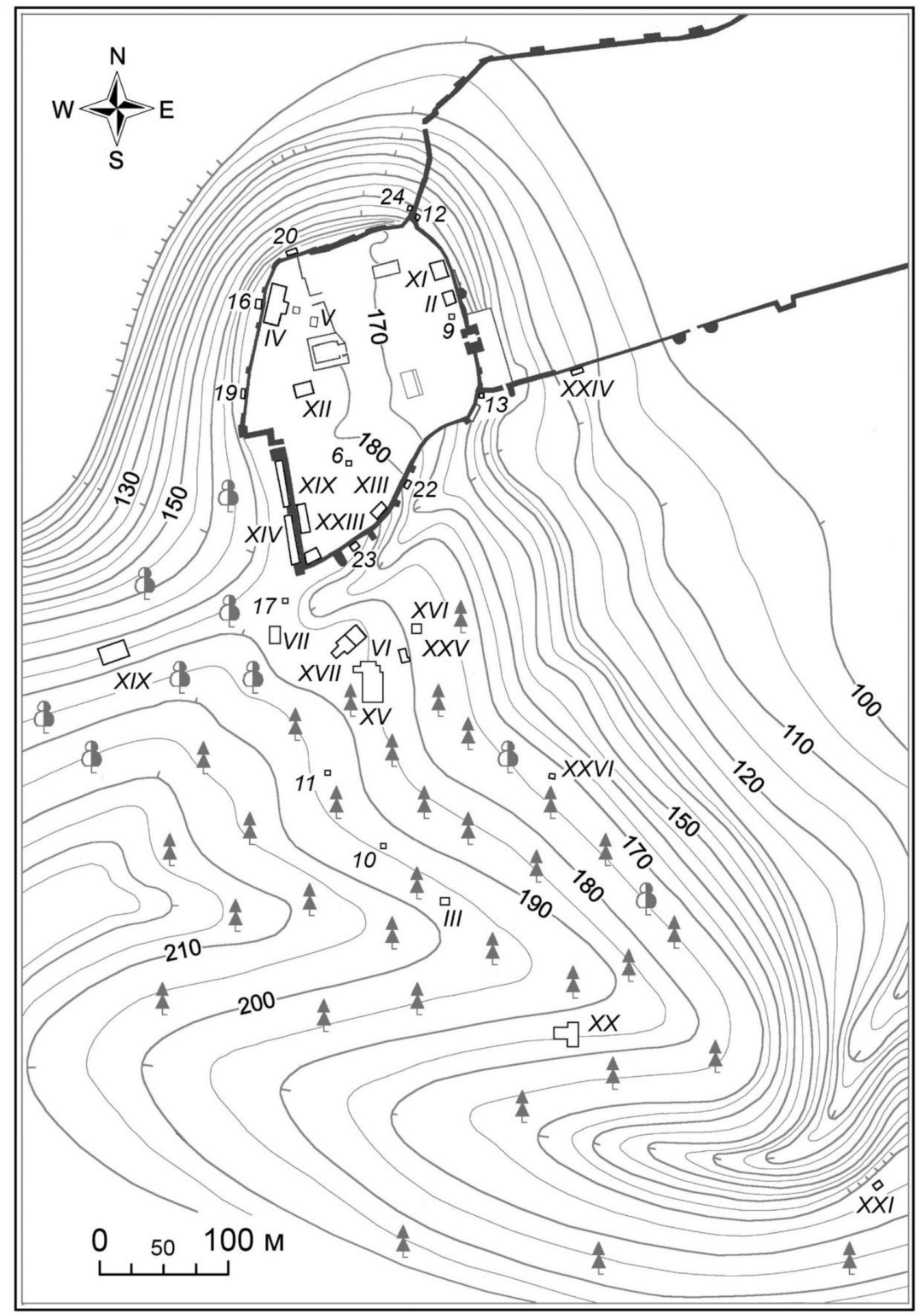

Рис. 1. Дербент. План цитадели Нарын-кала VI в. и Дербентского поселения с указанием места расположения раскопа XXV, а также ранее заложенных раскопов (обозначены римскими цифрами) и стратиграфических шурфов (обозначены арабскими цифрами) 


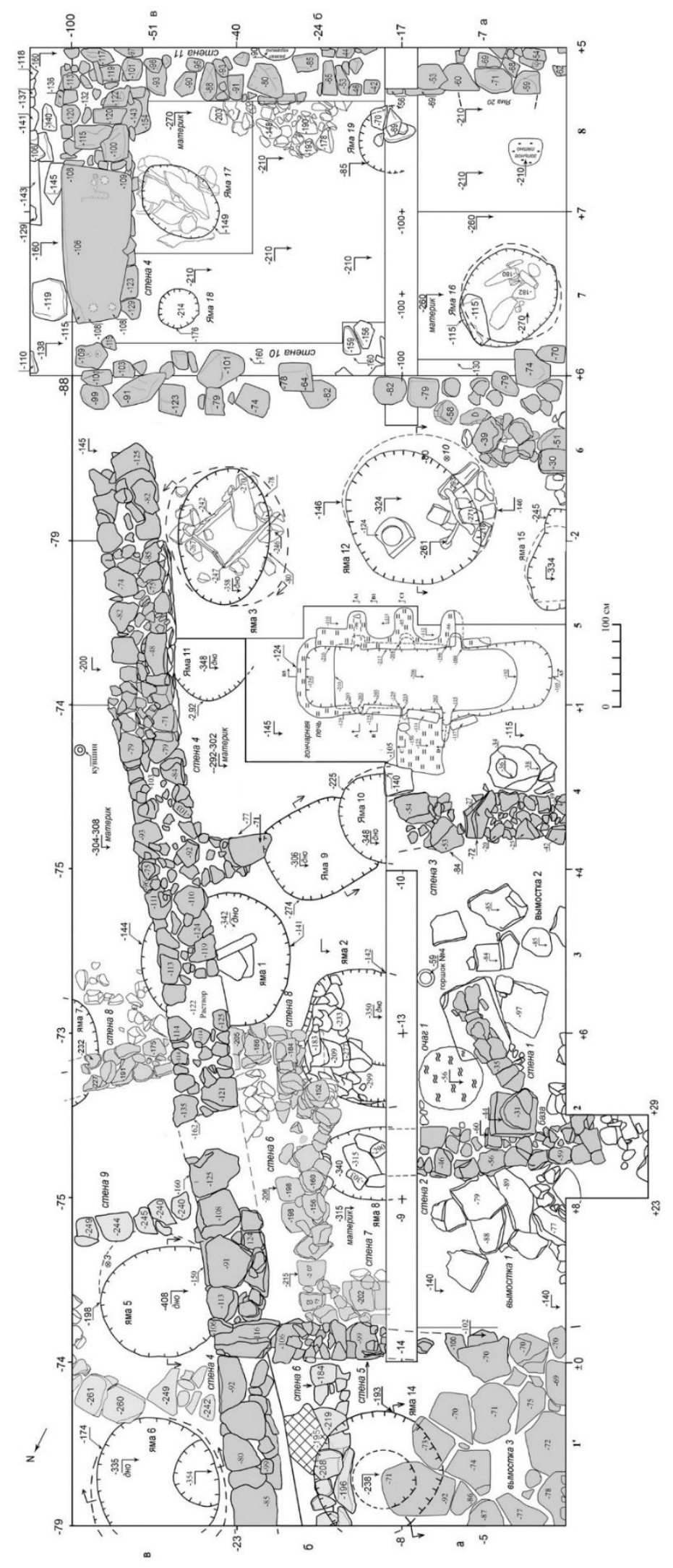

Рис. 2. Дербентское поселение. Раскоп XXV. Послойный план 9 (2012-21015 гг.) 

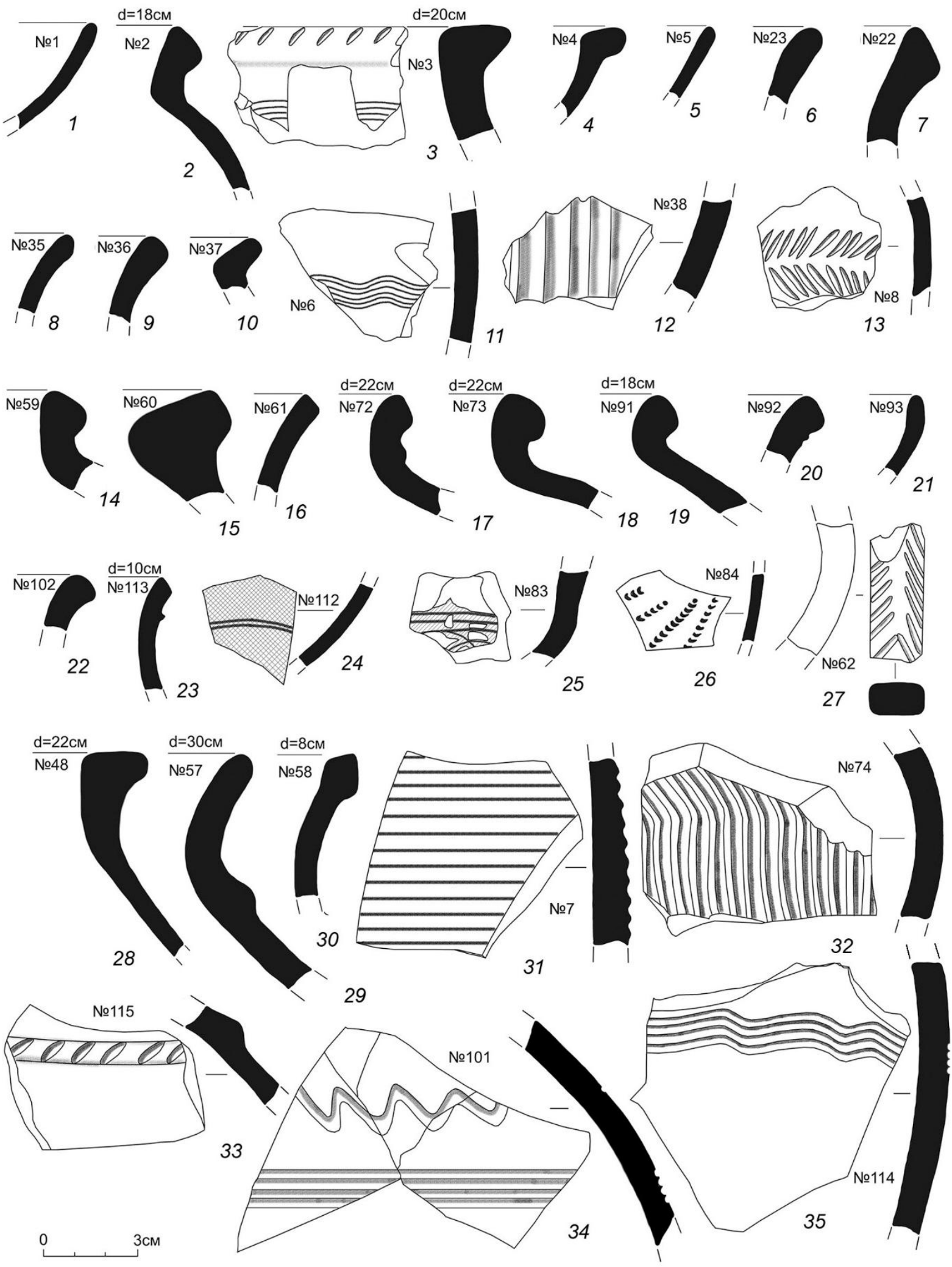

Рис. 3. Дербентское поселение. Раскоп XXV. Керамика слоя 1 

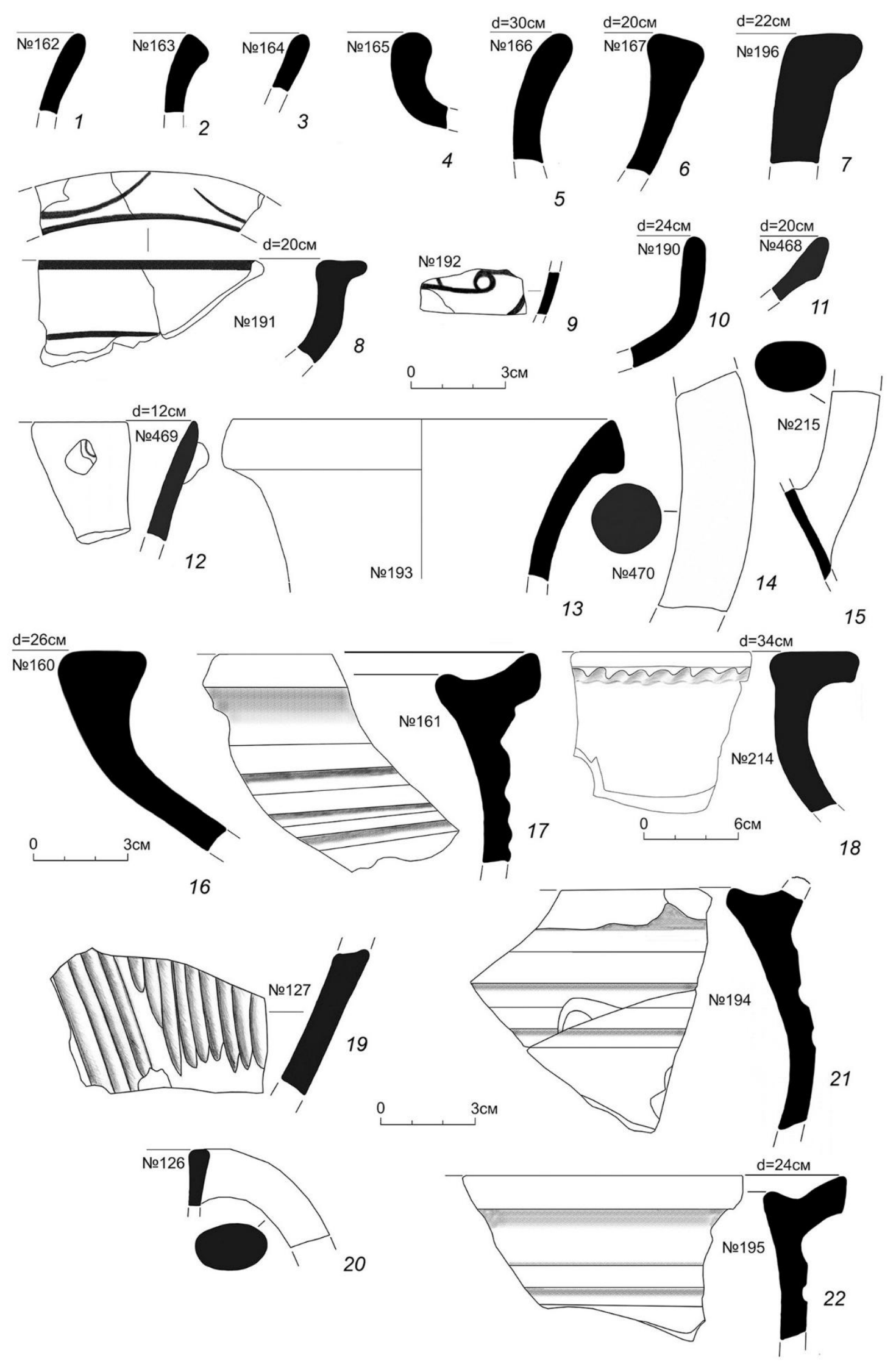

Рис. 4. Дербентское поселение. Раскоп XXV. Керамика из слоя 1 (1-18) и из каменного завала (19-22) 


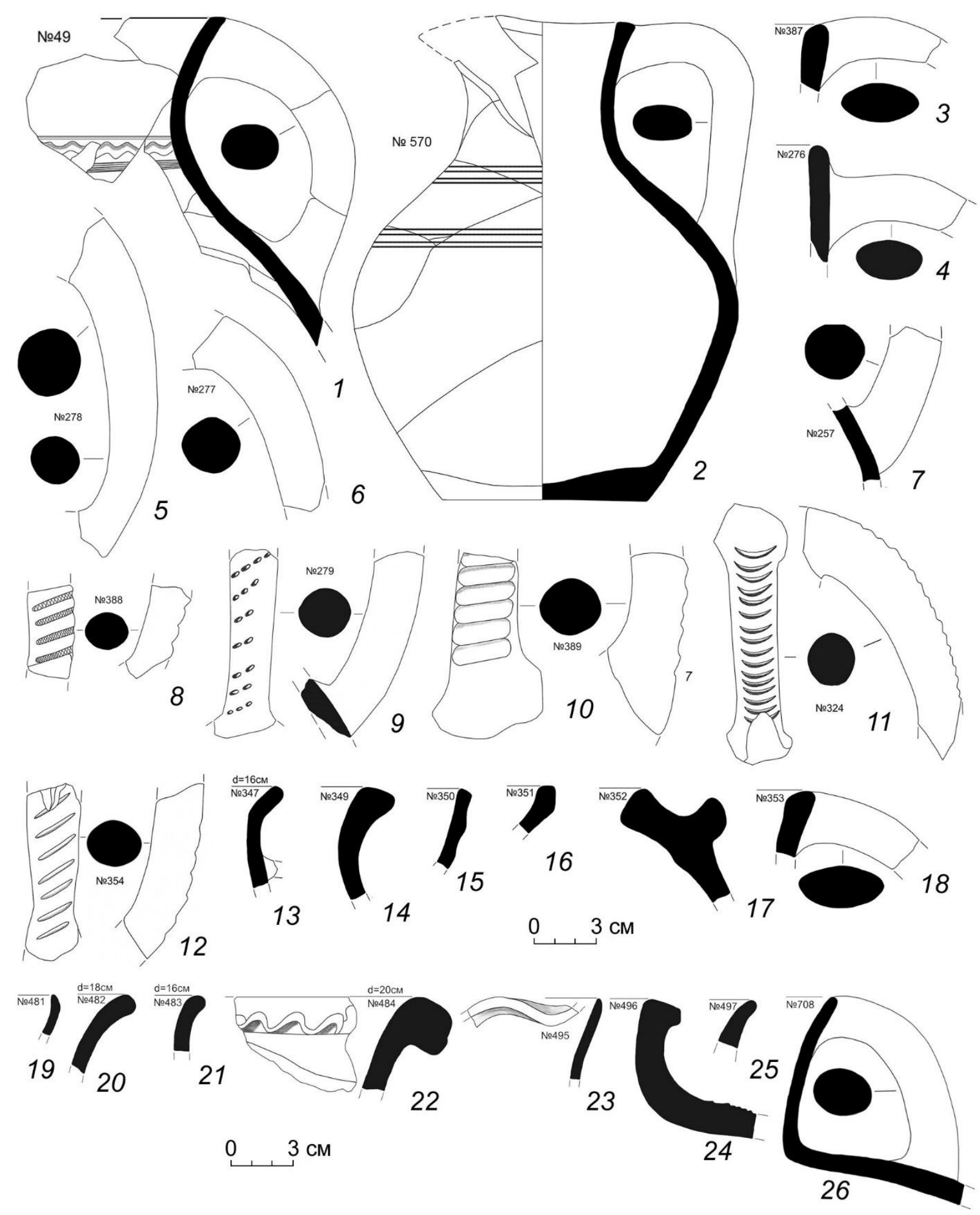

Рис. 5. Дербентское поселение. Раскоп XXV. Керамика из слоя 2 (1-18), зольного пятна $(12-18)$ и ямы 16 (19-26) 

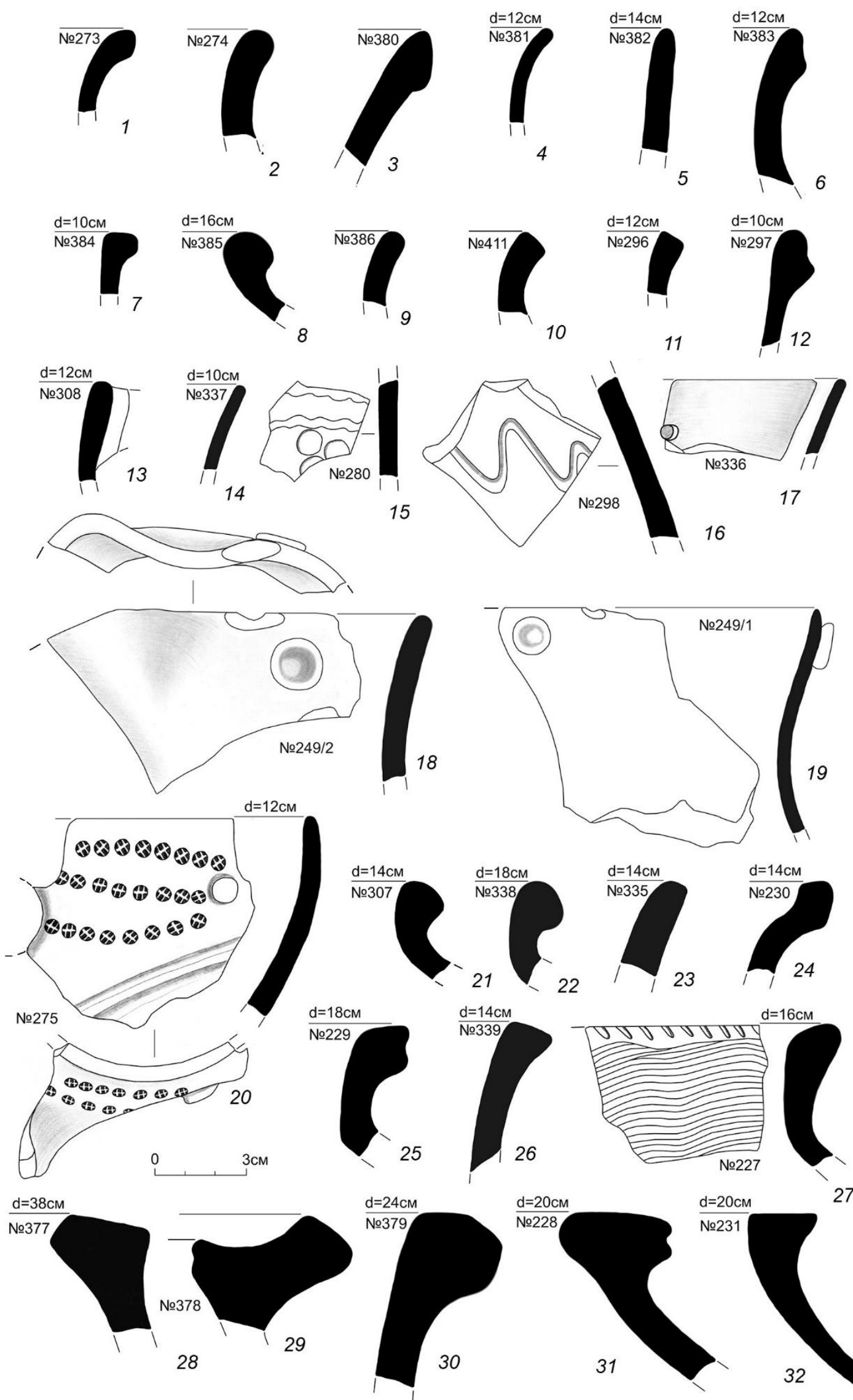

27

Рис. 6. Дербентское поселение. Раскоп XXV. Керамика слоя 2 

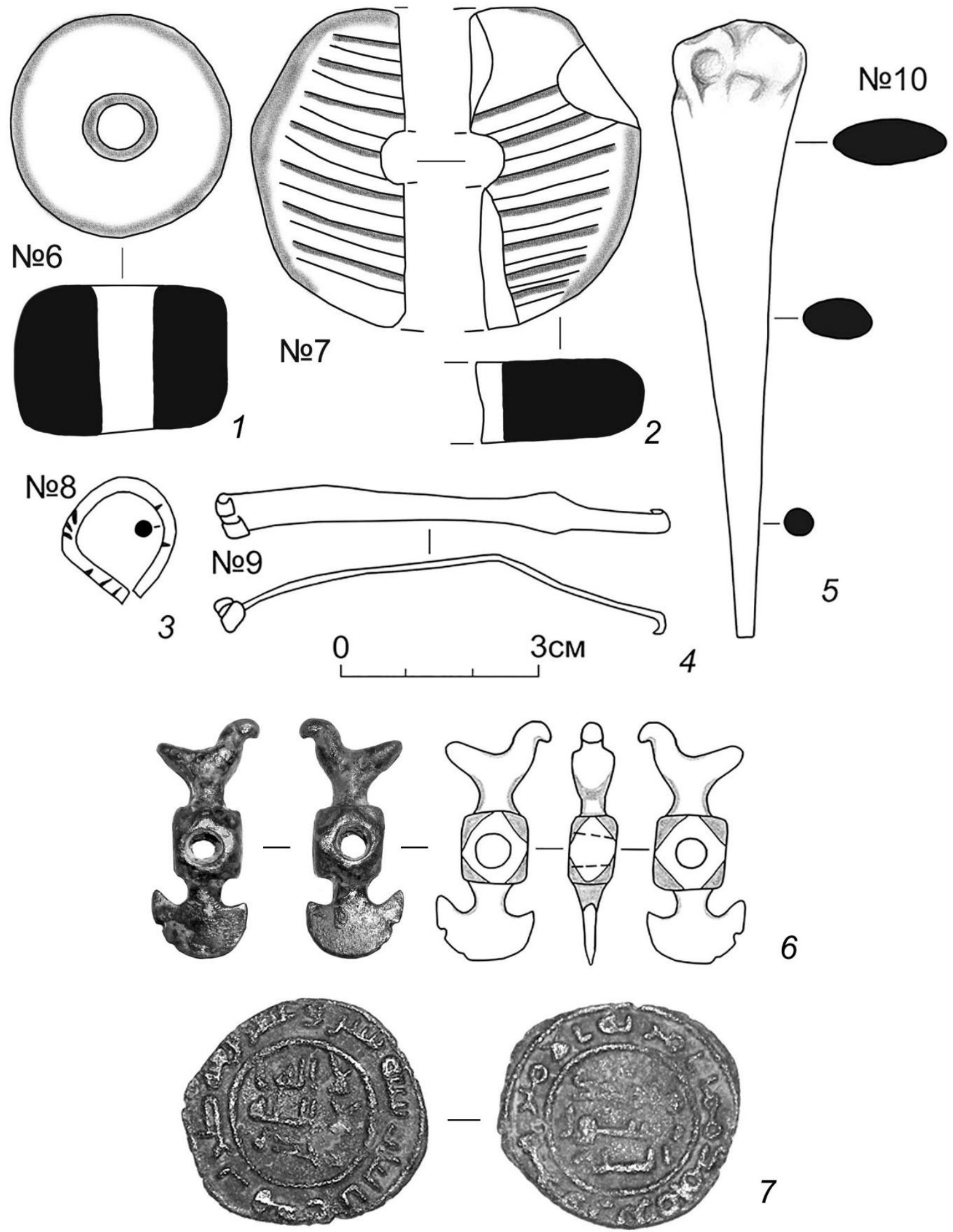

Рис. 7. Дербентское поселение. Раскоп XXV. Индивидуальные находки из слоя 2 (1-6) и медная монета из слоя 1 ( 7 - увеличено в 2 раза) 


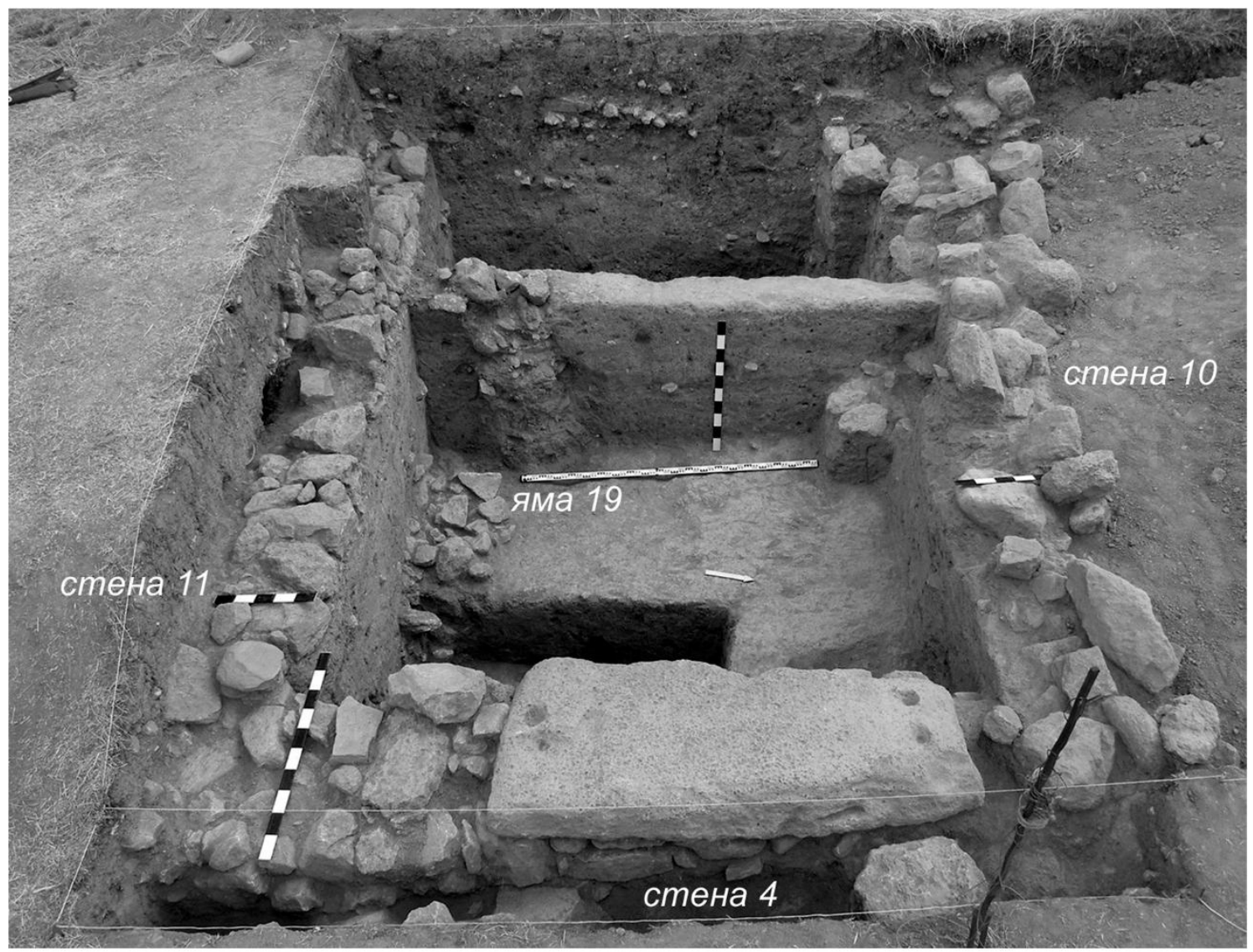

a

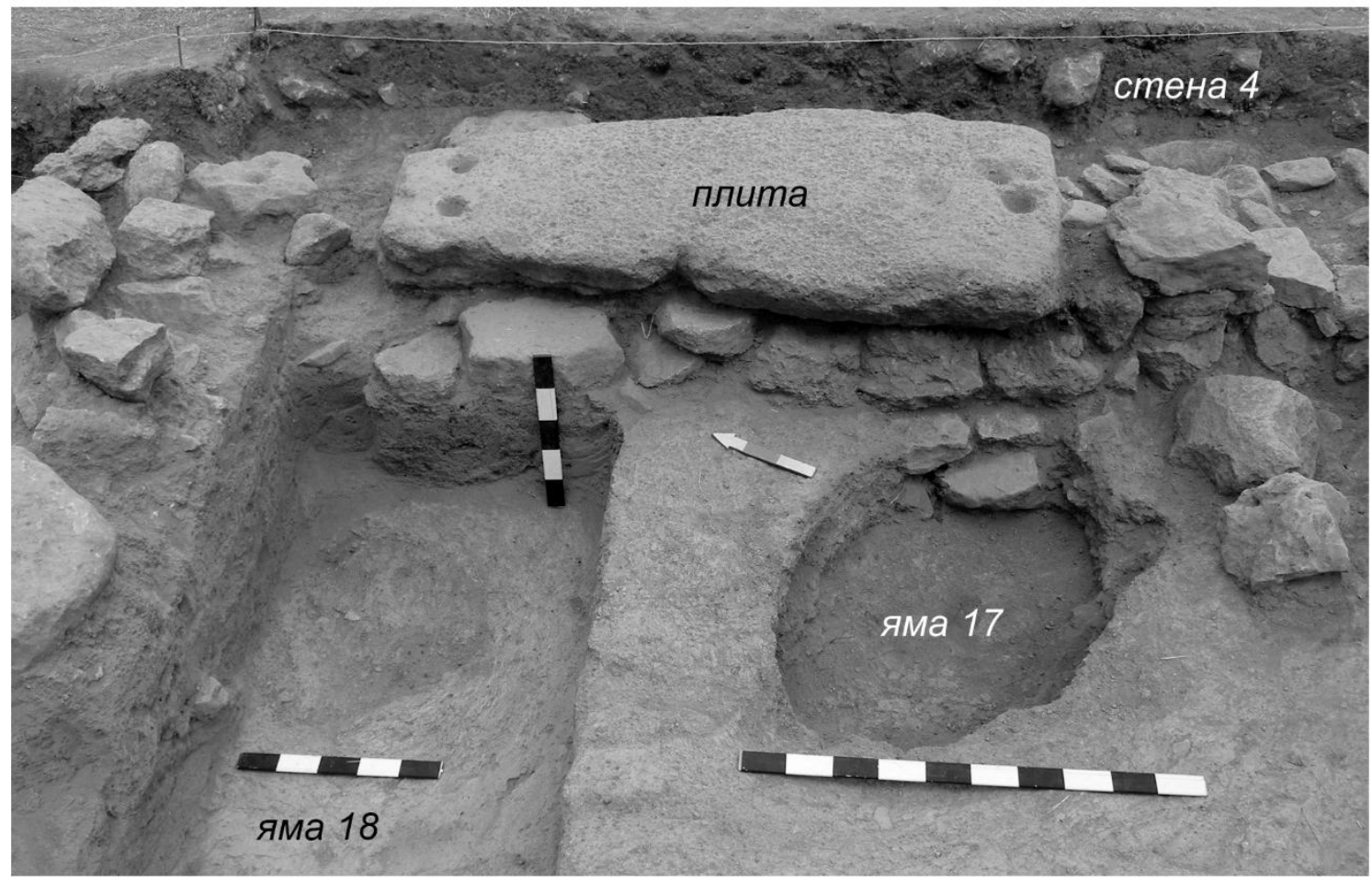

Рис. 8. Дербентское поселение.

Раскоп XXV: $a$ - вид южного участка с CBB, $\sigma$ - вид с Ю3З стены 4 с плитой и ям 17 и 18 


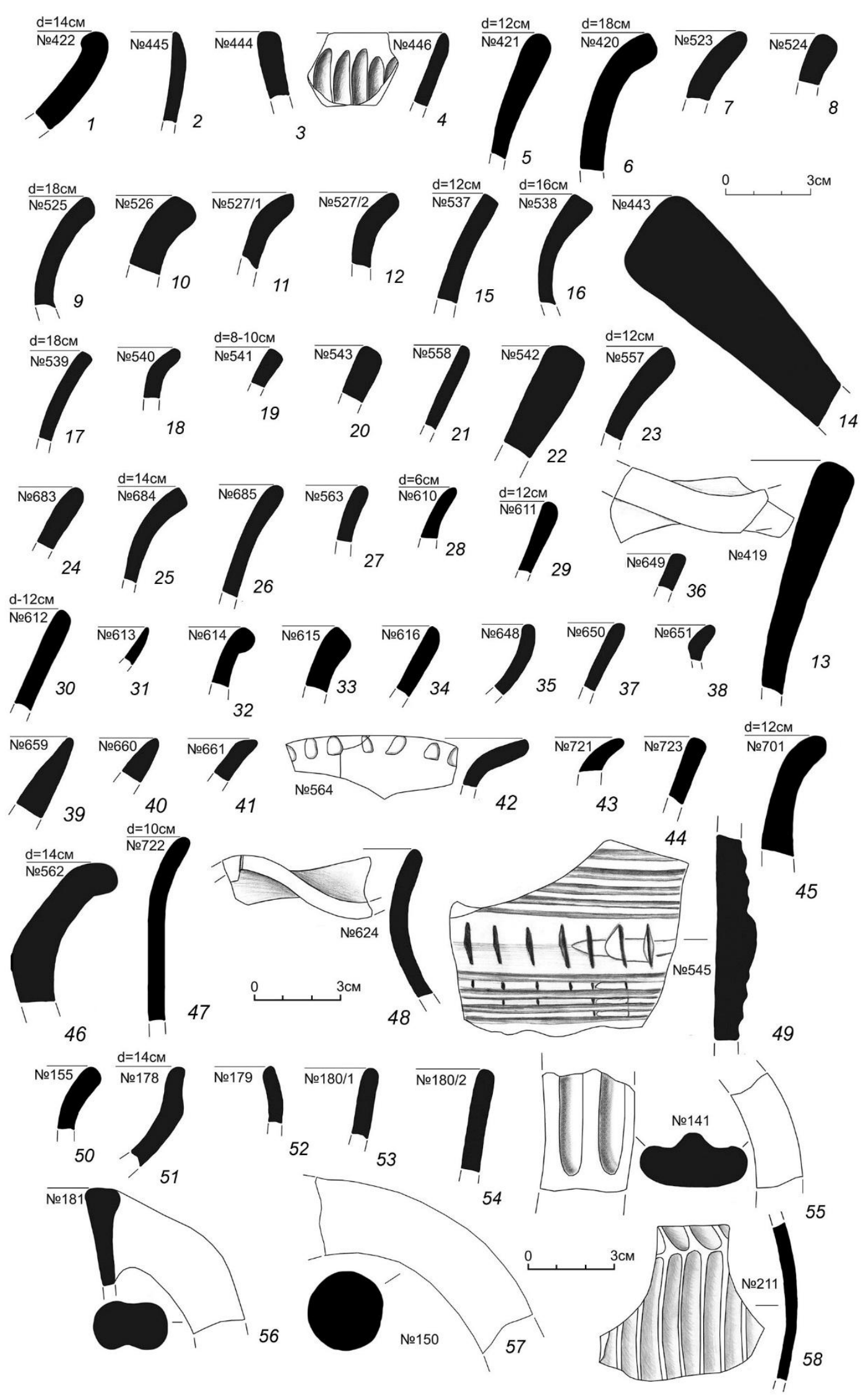

Рис. 9. Дербентское поселение.

Раскоп XXV. Керамика из слоя 3 (1-42, 45, 46, 48, 49), слоя 4 (43, 44, 47, 50-58) 

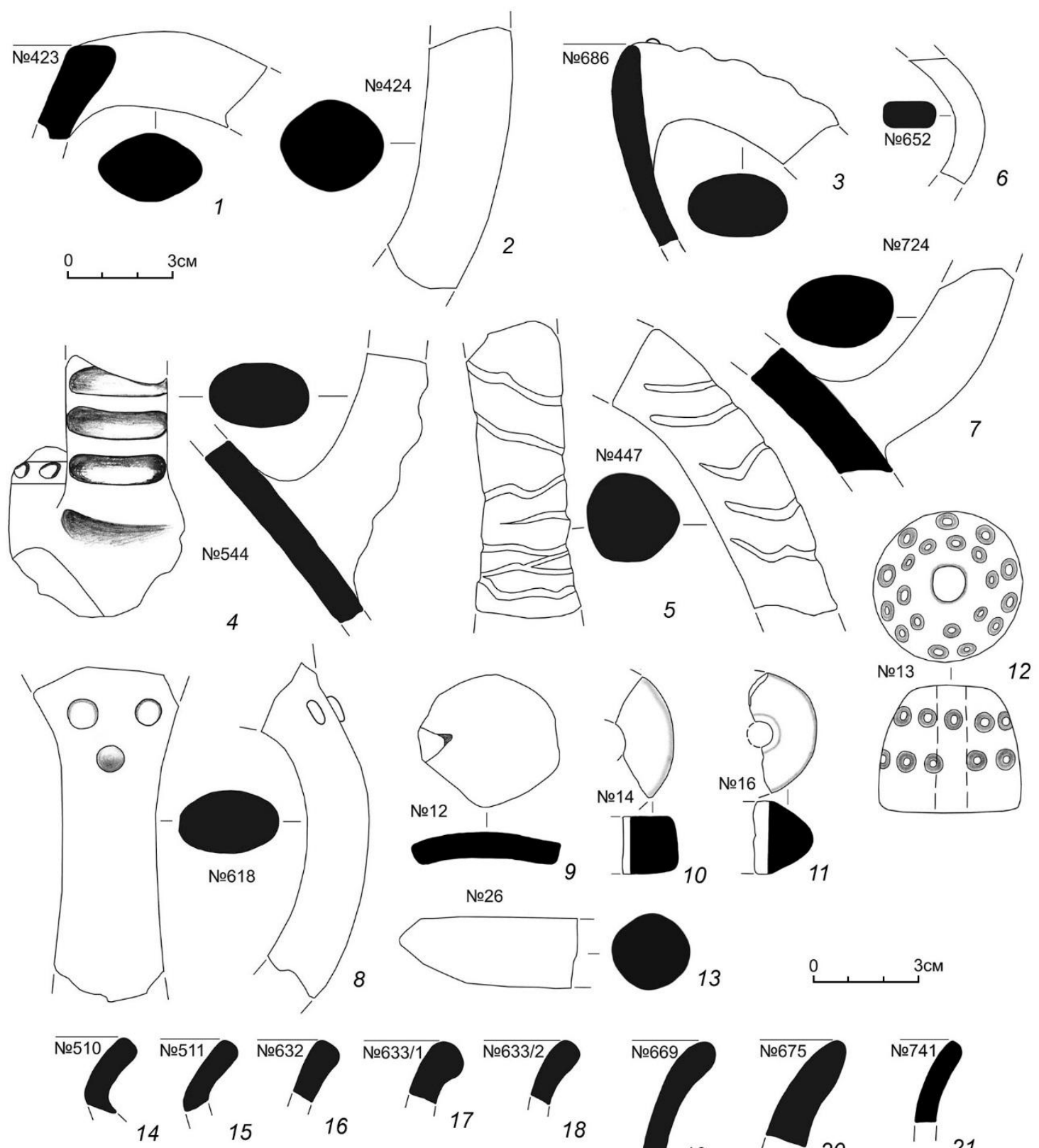

№13 12
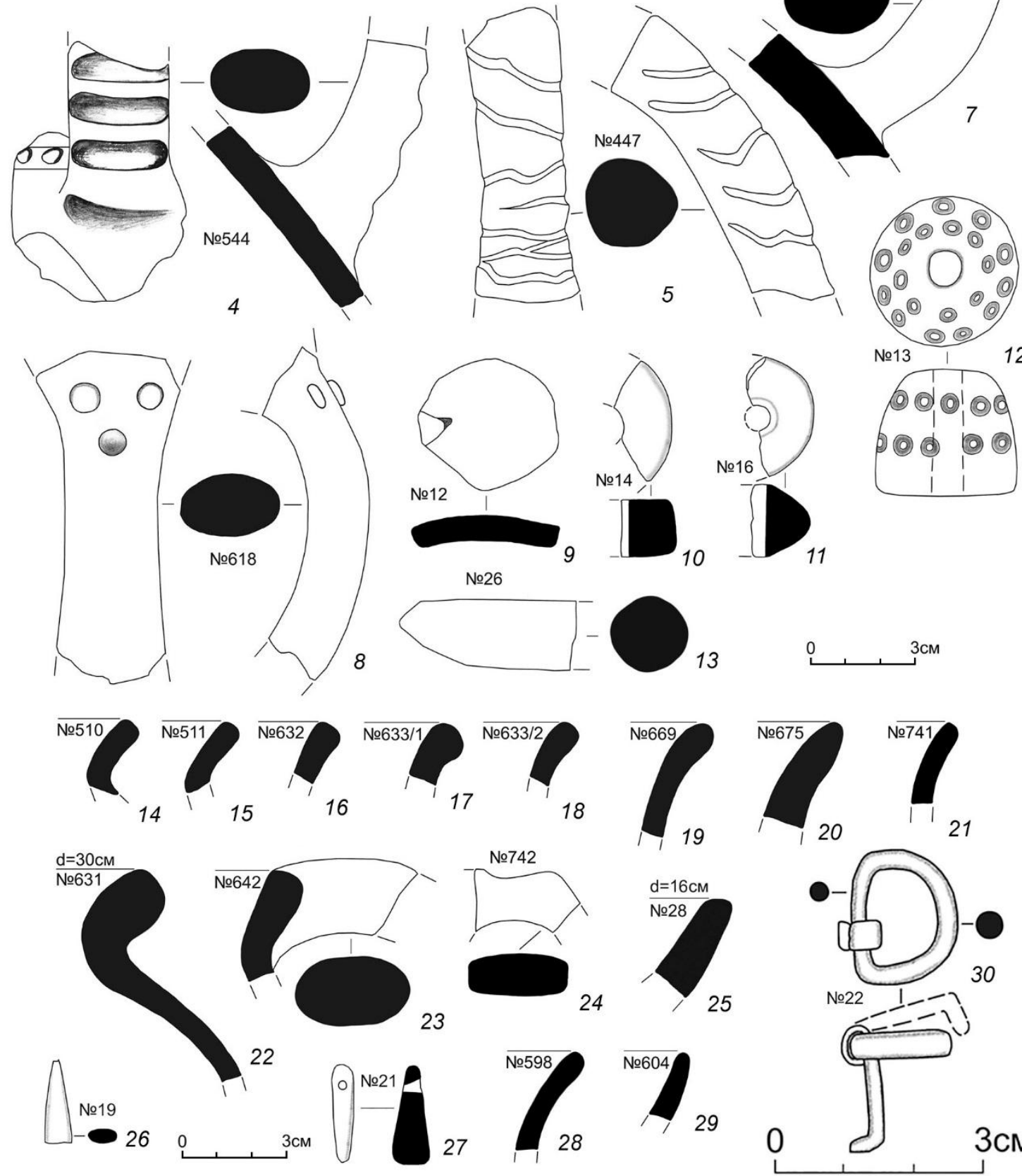

Рис. 10. Дербентское поселение.

Раскоп XXV. Фрагменты ручек $(1-6,8)$ и индивидуальные находки из слоя 3 (9-13), слоя 4 (7), находки из хозяйственных ям 17 (14-27) и 18 (28-30) 